\title{
Notional Architectonics of Consciousness and Transformation of the Existential and Systemic Concept "Model of the World" of Future Psychologists who Have Their Professional Activity in the Sphere of Psychological Counseling
}

\section{Смислова архітектоніка свідомості й екзистенціально-системний концепт реорганізації «картини світу» майбутніх психологів-консультантів}

\section{Svitlana Kalishchuk}

Ph.D. in Psychology, Assistant Professor, Doctoral Student, Psychology of Personality and Social Practices Department of Institute of Human Sciences, Borys Grinchenko Kyiv University, Kyiv (Ukraine)

ORCID ID: https://orcid.org/0000-0002-1749-7856

Researcher ID: F-4321-2019

E-mail: klana_@ukr.net

\section{Світлана Каліщук}

Кандидат психологічних наук, доцент, докторант кафедри психології особистості і соціальної практики Інституту Людини, Київський університет імені Бориса Грінченка, м. Київ (Україна)

\section{ABSTRACT}

The aim of the article. The issue concerning the specifics of notional architectonics of consciousness of future counseling psychologists is highlighted in the study

Address for correspondence, e-mail: kpnu_lab_ps@ukr.net Copyright: (c) Kalishchuk Svitlana

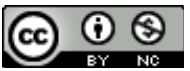

(c) Kalishchuk Svitlana

DOI (article): https://doi.org/10.32626/2227-6246.2020-48.154-174 
and the existential-systemic approach to the reorganization of their «model of the world» is described.

Methods. The "model of the world» of future counseling psychologists was studied using: A. Adler's "The earliest childhood memory» method, F. Fiedler's "Type of attitude toward others" methodology, modeling of "semantic universals" "model of the world» by A. Artemieva.

The results of the research. Four plans for the analysis of the notional dynamics of the "model of the world» of future counseling psychologists are examined, in particular: the formation of the "model of the world»; the correlation between the subjective model of the world and the objective world; plan for the content and functioning of the "model of the world»; the development or reorganization of the "model of the world». The structure of the significant relations in the world of future counseling psychologists and the patterns that they use is outlined. There have been established such attractors: methods of comprehending the "World" as a source of fear, sadness, shame, anger, disgust to confirm their own values regarding subjective image; behavioral programs of avoidance, requests for help, accession, destruction, rejection as a means of confirming established contacts and means of interaction with the "World»; situationally-subjective and neutral-indifferent types of attitude towards others accepted as the most effective forms of the relationship between "Me» and the "World"; contextual semantic universals "resource and intention" and "dynamics» as the genesis of the development and strength of the personality system. The existential and systematic approach to the reorganization of the notional architectonics of future counseling psychologists is described, which involves not only expanding the horizon of the identification of oneself and the world as a research, defining and adopting personal expert zones, but also as searching and establishing notional relationships between elements of the system due to the development of multidimensional psychological identification of oneself and the world.

Conclusions. The proposed diagnostic scheme for studying the "model of the world» of future counseling psychologists has ensured the construction of a notional model of the relationship between the constructs "Me» and "World». It has found out the parapharmal experience of constructing by the researchers their own architectonics of meanings, considering its genesis and primary components. Due to the multi-paradigmatic methodological foundations and the tasks of integrating experience with unlimited intrinsic intensity, the existential and system approach can be considered as an effective concept

(c) Kalishchuk Svitlana

DOI (article): https://doi.org/10.32626/2227-6246.2020-48.154-174 
DOI: https://doi.org/10.32626/2227-6246.2020-48 2020. ВИПУСК 48

for creative change of "crystallized" patterns, the discovery of new vectors of life changes, self-organization and evolution, due to the intrapsychic focus of transformational work and objective orientation.

Key words: meaning, "life style», "model of the world», existential and systemic approach, evolution, future counseling psychologists.

\section{Вступ}

Гносеологічна площина свідомості як «універсальної сили» еволюційних процесів (Бескова, 2001) виникає і розкривається в послідовному розрізненні й уточненні власного досвіду та зумовлює конструювання унікальної архітектоніки смислів особистості. Описуючи процес концентрації свідомості як «універсальної сили», І. О. Бескова наголошує, що у процесі збагнення глибинної суті суб'єкт проникає всередину об'єкта, стає цим об'єктом і переживає його як стан усередині себе. Закономірний інтерес дослідників викликає походження специфіки і модальності переживання «стану всередині себе», за якими диференціюються персональні суб'єктивні «картини світу» .

Дж. Б'юдженталь підкреслював, що сутність людського існування полягає у здійсненні постійних спроб налагодити ефективні збалансовані зв'язки між суб'єктивним й об'єктивним світами. Порушення балансу «наведених мостів» між конструктами «Я» $\mathrm{i}$ «Світ» породжує переживання тривоги або інші дистресові стани та зумовлює вирішальні аспекти уявлення людини про себе і свою систему цінностей, про засіб осягнення світу і бачення джерел сили й власної ефективності тощо (Бьюдженталь, 2001: 185). Емоційна дистресова складова виступає ознакою невідповідності між тим, як людина визначає себе та світ і формує інтенційну спрямованість або на введення поправки в існуючу смислову архітектоніку, або на кризове відкриття нових їі граней.

А. Ю. Агафоновим указано на важливе положення, яке розкриває і механізм, і генезу створення людиною психічної (C) Kalishchuk Svitlana

DOI (article): https://doi.org/10.32626/2227-6246.2020-48.154-174 
моделі реальності, що є смисловою її проекцією (Агафонов, 2003: 108). Зокрема, автор наголошує, що підтвердження істинності дійсного світу забезпечується винятково пізнанням змісту власного переживання щодо об’єктивної реальності. Саме таке переживання вибудовує певний зміст і «колір» психічної проекції дійсності та виступає головним чинником, що визначає відкриття нових смислів і необхідність реорганізації старих.

Існує певний перелік понятійних конструктів, що позначалися дослідниками в якості умов, причин або механізмів впливу на створення людиною парафернальної раритетної воронки, яка виконує функцію фільтрування сигналів зовнішнього світу та відбору з них тих, що відповідають змісту власного переживання щодо реального світу. До конструктів, що зумовлюються онтогенетичним розвитком, дидактичним і виховним досвідом людини та визначають походження досвіду інтерпретації подій об’єктивного світу й суб’єктивного їх переживання і трансляції, нами віднесено такі, як:

- «психологічна правда», «схема апперцепції» та «стиль життя» (Adler, 1932);

- «тип установки щодо інших» як механізм узагальнення і відчуження елементів світу від похідного досвіду та їх усталена і часто помилкова категоризація (Fidler, 1968);

- «семантичні універсалії» як форма «упаковування» досвіду взаємодії людини зі світом (Артемьева, 1999).

Зазначені дослідницькі конструкти складають питому вагу в імпліцитно заданій програмі диференціювання ракурсу осягнення, розуміння та переживання людиною світу i себе. Кожен із них, з одного боку, виступає вихідною умовою кристалізації з невичерпного зовнішнього впливу окремих граней, які виступають унікальними призмами відбору й акумуляції власного досвіду. 3 іншого, зумовлює «колористику» та накопичення парафермального узагальненого

(C) Kalishchuk Svitlana

DOI (article): https://doi.org/10.32626/2227-6246.2020-48.154-174 
полюса переживань, що створює смислову модель себе і світу - персональну «картину світу». «Стиль життя», «установка щодо інших» $\mathrm{i}$ «семантичні універсалії» являють собою стабільно-динамічні утворення та формуються у відповідний віковий період онтогенетичного розвитку людини. Взаємозв'язки між ними не є лінійними або причинно-наслідковими, але системотворчою засадою їх об'єднання виступає непереборний вплив на побудову суб'єктивної моделі об'єктивного світу і власні засоби осягнення свого життя та його якості. Тому окреслені конструкти розглядаються нами як точки зростання системи, у яких проявлено максимально повний набір можливостей смислової конструкції свідомості людини та потенційно закладено засоби її реорганізації.

Майбутні психологи-консультанти в період фахової підготовки усвідомлюють багатоваріативність суб'єктивних «картин світу», кожна з яких в окремої людини унікально репрезентує об'єктивний світ, надаючи перевагу тим граням сприйняття, які є домінантними в силу неповторно пережитого досвіду. Враховуючи, що «картина світу» майбутнього психолога-консультанта виступає простором розгортання його власних екзистенцій і професійного тезауруса, питання актуалізації та реорганізації його смислової моделі світу виступає необхідною умовою професіоналізації.

Мета статті - висвітлити специфіку смислової архітектоніки свідомості майбутніх психологів-консультантів та окреслити екзистенціально-системний підхід реорганізації їх «картини світу».

\section{Завдання статті}

1. Викласти модель дослідження «картини світу» майбутніх психологів-консультантів.

2. Представити екзистенціально-системний ракурс реорганізації смислової динаміки свідомості майбутніх психологів-консультантів. 


\section{Методи та методики дослідження}

«Картина світу» майбутніх психологів-консультантів досліджувалася з використанням проективного підходу та методів суб’єктивного шкалювання і суб’єктивної семантики, a came:

- методу «Найраніший дитячий спогад» А. Адлера, який зумовлений «схемою апперцепції» та «психологічною правдою» індивіда й визначає його «стиль і девіз життя» (Adler, 1932);

- методики Ф. Фідлера «Тип установки щодо інших» як цілісного індикатора ставлення до інших і як прояв інтегративної характеристики, що об'єднує перцептивні властивості, оцінний стиль, тотожність, спрямованість емоційних реакцій, самокритичність, модальність самоставлення й типові поведінкові тактики (Каліщук, 2014);

- моделювання "семантичних універсалій» «картини світу» за О. Ю. Артем'євою (Артемьева, 1999).

Контент-аналіз ранніх спогадів досліджуваних здійснювався за запропонованою О. В. Сидоренко схемою та складався з чотирьох етапів: аналізу змістових категорій і висування гіпотез; перевірки гіпотез; інсайтного осягнення «життєвого стилю»; уточнення й остаточного формулювання відкритої формули як життєвого «девізу» досліджуваного (Сидоренко, 2002). Проводився частотний аналіз (f) «девізу життя» за такими критеріями-дескрипторами, як:

1) зміст домінуючих переживань, що визначають типову для досліджуваного програму дій;

2) тип події;

3) відчуття приналежності.

Вага ознаки дескриптора підраховувалася за допомогою нормування - приведення до загального знаменника на засаді загальної кількості досліджуваних (f / N).

«Тип установки щодо інших» за методикою Ф. Фідлера розглядався нами як категоризація елементів світу, в основі

(C) Kalishchuk Svitlana

DOI (article): https://doi.org/10.32626/2227-6246.2020-48.154-174 
якої лежить когнітивна оцінна й емоційна диспозиції, що зумовлюють модальність, інтенсивність, глибину сприйняття та, відповідно, вибір корелятивних поведінкових реакцій.

Семантичне моделювання дало змогу побудувати сукупність міжпонятійних зв'язків елементів семантичного поля поняття «картина світу» досліджуваних.

Отримані діагностичні дані окреслили простір, у якому відтворено системотворчі грані смислової моделі світу майбутніх психологів-консультантів і визначено якісну характеристику атракторів - точок тяжіння і стабільних станів, до яких прагне система і які являють собою предметні критерії її реорганізації з метою зростання.

Загальну вибірку склали 444 досліджуваних із Запорізького національного університету (272 особи), Київського університету імені Бориса Грінченка (43 особи), Київського національного економічного університету імені Вадима Гетьмана (110 осіб) і Batumi Shota Rustaveli State University (19 осіб). Критерієм формування вибірки було визначено спрямування навчання та подальших професійних інтересів досліджуваних.

\section{Результати та дискусії}

Обрані для аналізу понятійні конструкти: «стиль життя», «тип установки щодо інших» $\mathrm{i}$ «семантичні універсалії» «картини світу» складають систему взаємодіючих елементів, які перебувають у множинних взаємозв'язках, що дає змогу провести декілька планів аналізу смислової динаміки «картини світу» досліджуваних, зокрема:

- план динаміки становлення «картини світу»;

- план відношення між суб’єктивною моделлю світу й об'єктивним світом;

- план змісту та функціонування «картини світу»;

- план розвитку або реорганізації «картини світу» .

Становлення «картини світу» відображається у процесі кристалізації патерна поведінки, який А. Адлер назвав (c) Kalishchuk Svitlana

DOI (article): https://doi.org/10.32626/2227-6246.2020-48.154-174 
«стиль життя». Автор стверджував, що «стиль життя» конгломерується зі значення, яке людина надає світу і самій собі, з мети і спрямованості власних зусиль, зі стійкого стилю оцінки та з певних підходів і засобів, що використовуються для вирішення життєвих проблем (Adler, 1932). Світ сприймається людиною через усталену «схему апперцепції», яка забезпечує трактування переживань не після сприйняття, а перед ним. Механізмом такого помилкового випереджального трактування виступає обов'язкове узгодження будь-якого трактування з первісним значенням, що було надано життю загалом і прийнято як власний «девіз життя» .

Відсоток позитивних «девізів життя» у вибірці досліджуваних (наприклад: «Жћити - це вивчати світ і насолоджуватися новими відкриттями», «Жиити - це відчувати задоволення від спроб навчитися новому і напрацювати корисний досвід») склав 8\%, що дещо перевищує відповідний показник у дослідженнях А. Адлера та, загалом, узгоджується $з$ теоретичними і практичними положеннями Індивідуальної психології. Формули життя у $92 \%$ досліджуваних майбутніх психологів-консультантів характеризуються фіксацією на негативних переживаннях і болісному досвіді, наприклад: «Жити - це сподіватися й активно шукати тих, на кого можна спиратися», "Жћити - це платити за проявлений інтерес болісними відчуттями й осудом значущих людей», «Жити - це не очікувана, але обов'язкова зустріч із тим, що лякає і викликає відразу», «Жиити - це відчувати нерішучість і тривогу, але витримувати осуд і виконувати доручення значущих людей, бути відповідальним», «Зึити - це бути оточеним опікою й увагою», «Жити - це витримувати тягар чужої прихованої інформації та переживати недовіру і відчуження», «Жиити - це долати зовнішню ворожнечу та постійно шукати підтримку» тощо. Частотний аналіз критеріїв-дескрипторів оцінки «девізу життя» представлено у табл. 1.

(C) Kalishchuk Svitlana

DOI (article): https://doi.org/10.32626/2227-6246.2020-48.154-174 
Дескрипторний розподіл значень «девізу життя» досліджуваних

\begin{tabular}{|l|l|}
\hline \multicolumn{1}{|c|}{ Критерії } & \multicolumn{1}{|c|}{ Дескриптори (в дужках - вага ознаки) } \\
\hline Зміст домінуючих & Страх - уникання $(0,73)$, сум - прохання \\
у спогаді пережи- про допомогу $(0,65)$, сором - приєднання \\
вань і відповідних & $(0,43)$, гнів - руйнування $(0,36)$, відраза - \\
їм програм дій & $\begin{array}{l}\text { відкидання }(0,33), \text { радість - повторення } \\
(0,21), \text { інтерес - вивчення }(0,2), \text { подив - пе- } \\
\text { реключення }(0,12)\end{array}$ \\
\hline Тип події & $\begin{array}{l}\text { Травматична }(0,62), \text { нова ситуація }(0,42), \\
\text { нейтральна }(0,23)\end{array}$ \\
\hline $\begin{array}{l}\text { Відчуття прина- } \\
\text { лежності }\end{array}$ & Ми-ситуація» $(0,87)$, Я-ситуація» $(0,13)$ \\
\hline
\end{tabular}

Метод «Найраніший дитячий спогад» дав змогу визначити, що лінза переломлення майбутніми психологами-консультантами реального світу залежна від умов і механізмів становлення їх «картини світу». Такими умовами виступають травматичні події $(0,62)$ і ситуації, пов'язані зі взаємодією зі значущими близькими людьми $(0,87)$. Домінуючі емоції, а саме: страх $(0,73)$, сум $(0,65)$, сором $(0,43)$, гнів $(0,36)$, відраза $(0,33)$, виступають механізмами, які функціонально вибудовують фільтри сприйняття та забезпечують знаходження маркерів, що підтверджують актуальність, модальність, силу впливу, значення, ступінь емоційної фіксації на відповідних внутрішніх і зовнішніх подіях. Детермінується такий пристосувальний комплекс, згідно з А. Адлером, «схемою апперцепції», яка містить уявлення про себе і світ на двох рівнях. Перший - це рівень конструкції образів себе і світу, що складається з елементів, зв'язків i станів особистості. У нашому випадку - це перевага негативної модальності емоційних і дієвих програм і фіксація на травматичності минулого досвіду взаємодії з оточуючи(C) Kalishchuk Svitlana

DOI (article): https://doi.org/10.32626/2227-6246.2020-48.154-174 
ми. Другий рівень уявлень «схеми апперцепції» зумовлений суб'єктивною інтерпретацією того, що відчувається почуттями. Це положення означає, що дистресова складова «картини світу» досліджуваних є суб'єктивно «перевіреним» i «доказовим» інструментом увімкнення емоційних (страх, сум, гнів, сором, відраза) та поведінкових (уникнення, прохання про допомогу, приєднання, руйнація, відкидання) програм. Крім того, суб'єктивна інтерпретація досліджуваних має постійний ракурс спрямованості на підтвердження власної «психологічної правди», яка запускає домінуючі емоційні програми та розхитує баланс між суб'єктивним та об'єктивним світами. 92\% досліджуваних мають концепцію життя, що проявляє почуття їх власної невідповідності та незбалансованості між конструктами «Я» $\mathrm{i}$ «Світ».

Аналіз відношення між суб'єктивною моделлю світу й об'єктивним світом досліджуваних, зокрема, сформованим у них ракурсом реагування на зовнішні стимули, здійснювався діагностикою типу установки щодо інших (Fidler, 1968). Поняття «тип установки» Ф. Фідлера відповідає поняттю «стиль життя» А. Адлера й означає інтегральну мету або домінантний намір як переважну інтенцію. Ф. Фідлер підкреслював, що тип установки слід розглядати не як стильову характеристику особистості й особливості її когнітивного або перцептивного стилю, що виступають похідними від поведінки, а, навпаки, як первинну характеристику особистості та стійку константу, тобто, як прийняту концепцію (Fidler, 1968). Тип установки щодо інших являе собою фіксовану здатність певним чином сприймати інших людей та обставини й особливим чином реагувати на них. Визначений тип установки дає змогу відповісти на запитання: «Як засвоєний індивідом соціальний досвід i «психологічна правда» переломлюються свідомістю та проявляють себе у сприйняттях, оцінках і діях?» Специфіка сформованого типу установки позначається на властивості реагувати на обставини 3 постійністю, незалежною від часу, людей і подій.

(C) Kalishchuk Svitlana

DOI (article): https://doi.org/10.32626/2227-6246.2020-48.154-174 
DOI: https://doi.org/10.32626/2227-6246.2020-48

Операційною процедурою співвідношення рівнів вираження двох індексів методики (LPC - індексу оцінки найменш бажаної людини й ASO - індексу передбачуваної тотожності між протилежними образами реальних людей: найбільш бажаної та найменш бажаної людини) встановлюється певний тип установки кожного досліджуваного. Отримано таку представленість типів установки щодо інших:

- активно-позитивний (f $=68,15 \%)$;

- ффункціонально-діловий (f $=79,18 \%$ );

- ситуативно-суб'єктивний ( $\mathrm{f}=193,44 \%)$;

- нейтрально-байдужий (f = 104, 23\%);

- приховано-негативний $(f=0)$.

Діагностика типу установки розкрила перевагу в досліджуваних суб'єктивно-ситуативного типу ( $\mathrm{f}=193,44 \%$ ), який вирізняється схильністю диференціювати своє ставлення до інших залежно від поточного емоційного стану, ситуативного сприйняття обставин і викривленого відчуття прийняття чи неприйняття себе оточуючими. Слабкий емоційний контроль і відсутність емоційної стабільності призводять до різких коливань настрою під впливом зовнішніх чинників, які сприймаються як несприятливі й некомфортні. В основі нейтрально-байдужого типу установки (f $=104,23 \%$ ) лежить закритість особистості від емоційного втручання до себе і відсутність прояву інтересу й емпатії до інших. Індивід відсторонений від інших на емоційному рівні, тому спілкування носить стриманий характер, вирізняється поверховістю та відчуженістю. Формування такого типу є наслідком ранньої травматизації і помилкового рішення уникати близьких емоційних стосунків. Функціонально-діловий $(f=79,18 \%)$ й активно-позитивний ( $f=68$, $15 \%$ ) типи установки у вибірці досліджуваних представлені незначно ( $\mathrm{M}=89 ; \sigma=107,6)$. Високе значення показника стандартного відхилення підкреслює неоднорідність і нелінійність формування типу установки щодо інших, який виступає зовнішньою і багатоваріативною формою прояву (C) Kalishchuk Svitlana

DOI (article): https://doi.org/10.32626/2227-6246.2020-48.154-174 
сформованого «девізу життя» досліджуваних. Узагальнюючи існуючі відношення між суб'єктивною моделлю світу й об'єктивним світом, можна констатувати, що категоризація зовнішніх об'єктів та елементів системи, до якої належать досліджувані, характеризується негативною диспозицією, яка, відповідно, впливає на вибір корелятивних їй поведінкових реакцій (ситуативно-суб'єктивних і нейтрально-байдужих) із домінуючими діями відкидання й уникання.

Аналіз змістової складової «картини світу» передбачав відкриття «семантичних універсалій» «картини світу» майбутніх психологів-консультантів, які закінчують навчання (4-й курс бакалаврату та 1-й і 2-й курси магістратури, всього 67 досліджуваних). Респонденти надали 1334 описові характеристики «картини світу», 3 яких частотним аналізом відібрано ті, що зустрічалися у $75 \%$ (f $=50)$ досліджуваних. Визначено дванадцять «семантичних універсалій», а саме: «особливий», «щастя», «проблемний», «змінний», «кольоровий», «багатогранний», «гарний», «справедливий», «складний», «безмежний», «активність», «інтерес» . Ієрархічним кластерним аналізом за допомогою IBM SPSS Statistics (версія 22) вирахувано два кластери, які можна розглядати як семантичний базис «картини світу» майбутніх психологів-консультантів. Перший має назву «Ресурс та інтенція». Його складають такі семантичні універсалії: «кольоровий», «гарний», «безмежний», «щастя», «особливий», «справедливий», «інтерес». Другий включає в себе елементи: «багатогранний», «складний», «активність», «проблемний» $\mathrm{i}$ «змінний». Другий кластер умовно названо «Динаміка». Коло визначених семантичних універсалій і базових семантичних координат «картини світу» майбутніх психологів-консультантів виступає контекстною універсалією. Таку універсалію як семантичний код можна розповсюдити на генеральну вибірку відповідно до методологічних положень психології суб'єктивної семантики О. Ю. Артем’євої (Артемьева, 1999).

(C) Kalishchuk Svitlana

DOI (article): https://doi.org/10.32626/2227-6246.2020-48.154-174 
DOI: https://doi.org/10.32626/2227-6246.2020-48

Отримані діагностичні дані окреслили простір, у якому відтворено системотворчі грані смислової моделі світу майбутніх психологів-консультантів. Зокрема, визначено якісну характеристику точок тяжіння і «стабільних» станів, а саме: структуру значущих зв'язків світу досліджуваних i патернів, які вони використовують. Такими атракторами установлено:

1) засоби осягнення «Світу» як джерела страху, суму, сорому, гніву, відрази для підтвердження власних значень відносно суб'єктивного його образу;

2) поведінкові програми уникнення, прохання про допомогу, приєднання, руйнації, відкидання як засоби підтвердження налаштованих зв'язків і засобів взаємодії зі «СвіTOM»;

3) ситуативно-суб'єктивний i нейтрально-байдужий типи установки щодо інших як налаштовані й найефективніші форми взаємовідносин між «Я» і «Світом»;

4) контекстні семантичні універсалії «ресурс та інтенція» $\mathrm{i}$ «динаміка» як генези розвитку i сили особистісної системи.

Зазначені атрактори зумовлюють смислотворення щодо того, що відбувається 3 досліджуваними незалежно від масштабу події. Тому вони виступають предметними критеріями концепції життя досліджуваних і можуть ураховуватися як зони реорганізації смислової архітектоніки їх «картини світу».

Логіка «реорієнтації» життєвого стилю в парадигмі індивідуальної психології А. Адлера полягає у дослідженні стилю життя, досягнення інсайту та розуміння його, що і викликає закономірну реорієнтацію. Згідно з А. Адлером, зміни уявлення про життя і своє місце в ньому неминуче викликатимуть зміни у стилі поводження (Adler, 1932). О. В. Сидоренко, розкриваючи методичну процедуру «Реорієнтаційного тренінгу», наголошує: «Реорієнтація - це не кардинальні зміни у процесі життя, а розкриття нових можливостей, не (c) Kalishchuk Svitlana

DOI (article): https://doi.org/10.32626/2227-6246.2020-48.154-174 
виправлення помилок, а пошук нових орієнтирів, це неочікуване розширення простору, розсунення психологічних горизонтів, часто болісне» (Сидоренко, 2001: 233).

Екзистенціально-системний ракурс впливу на життєвий стиль забезпечує дію механізму «збирання себе» і зміну зв'язків і відношень між елементами системи шляхом розширення життєвого світу. Така «реорганізація» зумовлюється генеративною властивістю людини як складної системи до саморуху і самотрансформації, якій властива якість самовіднесення. Е. Морен указує, що складна система - «це не просто організація ефективності й автоматичної точності функціонування. Це створення ретроактивної цілісності, наділеної власними організаційними властивостями» (Морен, 2013: 238). Екзистенція - це «якість буття, яке безперервно виробляє себе і яке руйнує себе, як тільки відбувається неочікуваний збій у виробництві себе або регенерації» (Морен, 2013: 260).

Отже, екзистенціально-системний підхід реорганізації смислової архітектоніки майбутніх психологів-консультантів передбачає не тільки розширення горизонту бачення себе і світу як дослідження, визначення та прийняття власних експертних зон, а й пошук і встановлення смислових взаємозв'язків між елементами системи завдяки розвитку багатомірності психологічного бачення себе і світу. Наприклад, зв'язків між болісними відчуттями дитинства (випробування самотністю, туга з горя, безмежний відчай, тремтіння від страху, страждання від невизначеності, гіркота гніву, паніка від почуття втраченості) та розвитком творчості у самотності, чуйності до переживання суму, мобілізації сил від відчаю, відваги, породженої страхом, можливостей, що відкриваються невизначеністю, сили, що викликається люттю, самодослідження i, як результат, наснагою натхнення жити (Шнайдер, 2015).

Методологічні засади екзистенціально-системного концепту складають положення екзистенціально-феноменоло(C) Kalishchuk Svitlana DOI (article): https://doi.org/10.32626/2227-6246.2020-48.154-174 
DOI: https://doi.org/10.32626/2227-6246.2020-48 2020. випуск 48 гічної парадигми, екзистенціально-гуманістичної психотерапії, психодрами та системного моделювання. Окреслений інтегративний мультипарадигмальний підхід реорганізації «картини світу» майбутніх психологів-консультантів спрямований на:

1) урахування багатомірності екзистенцій людини в силу непередбачуваності й невизначеності світу;

2) інтегрування різних сторін особистості й різного ставлення до екзистенціальних даностей: часу, життя, смерті, спілкування, любові, самотності, свободи, відповідальності, вибору;

3) об'єднання болісного досвіду дитинства і досвіду непростих життєвих ситуацій;

4) здійснення еволюціонування, відштовхуючись від «кристалізованих» патернів поводження;

5) розвинення внутрішніх ресурсів: творчості, цікавості, уяви;

6) відкриття безмежності власної інтенціальності у переживанні «життєвих парадоксів» (Шнайдер, 2015);

7) забезпечення екологічності процесу реорганізації.

Пошуковим полем реорганізації смислової архітектоніки виступає інтрапсихічна реальність майбутніх психологів-консультантів, їх занурення всередину себе, у свій центр, у центр своєї суб’єктності (Бьюдженталь, 2001: 143). Фокусом і механізмом реорганізації є відкриття парадоксальних смислів і парадоксальна конфронтація із самим собою, зі своєю власною ідентичністю й тим світом, який досліджувані створили для себе.

Предмет екзистенціально-системної реорганізації смислової архітектоніки свідомості майбутніх психологів-консультантів об'єднує чотири складові:

- подолання звичних стилів реагування та «кристалізованих» патернів, знаходження засад співіснування емоційних і когнітивних протилежностей шляхом парадоксального відкриття нових смислів;

(C) Kalishchuk Svitlana

DOI (article): https://doi.org/10.32626/2227-6246.2020-48.154-174 
- осягнення себе, свого місця у міжособистісному просторі, системної організації взаємовідносин з іншими як елементами системи, визначення якості та модальності зв'язків, установлених у системі між елементами;

- розвиток багатомірності себе і світу, встановлення нових напрямків руху, можливостей розвитку, інтеграція актуального, афективного і кінестетичного рівня переробки досвіду;

- формування ставлення до еволюціонування особистості як прийняття виклику жити.

Екзистенціально-системний ракурс реорганізації смислової архітектоніки свідомості віддзеркалює ідею Д. Леонтьєва про концептуалізацію «нерівноважної персонології» як теорії самоорганізованої особистості, що «знаходиться у безперервній динамічній взаємодії з умовами свого існування і яка еволюціонує через постійне зростання складності й внутрішньої реорганізації» (Леонтьев, 2018: 102).

\section{Висновки}

Запропонована діагностична схема дослідження «картини світу» майбутніх психологів-консультантів забезпечила побудову смислової моделі взаємовідношень конструктів «Я» та «Світ» і розкрила парафермальний досвід конструювання досліджуваними власної архітектоніки смислів з урахуванням її ґенезису й первісних складових.

Діагностований у майбутніх психологів-консультантів «кристалізований» патерн сприйняття, оцінки, відчуття себе і світу й особливостей дієвого реагування є інтегрованим засобом досягнення цілей і встановлює один із багатьох альтернативних варіантів їх життя. Виявлено фіксацію на травматичному дитячому досвіді з перевагою програм уникнення, прохання про допомогу, приєднання, руйнації, відкидання. Визначено, що суб'єктивна концепція світу зумовлює поведінку в силу того, що почуття є проявом впливу не реальних фактів, а суб'єктивного їх інтерпретування че-

(C) Kalishchuk Svitlana

DOI (article): https://doi.org/10.32626/2227-6246.2020-48.154-174 
рез механізм «психологічної правди». Водночас «розвиток та інтенція» i «динаміка» як узагальнені чинники семантичного простору «картини світу» досліджуваних означили ïх уявлення про світ як тло прояву i сховище позитивних імпліцитно заданих перспектив і про світ як об'ємний, рухливий, непередбачуваний, реагуючий на активність людини неконтрольованими, несподіваними резонансами.

Отже, діагностовані предметні критерії смислової моделі майбутніх психологів-консультантів можна розглядати як біфуркаційні точки побудови їх суб’єктивної концепції світу, що детермінують необхідність і засоби їі реорганізації, зокрема, в екзистенціально-системному ракурсі. Екзистенціально-системний підхід у силу мультипарадигмальних методологічних засад і завдань інтегрувати минулий досвід із безмежною власною інтенціальністю, в силу інтрапсихічного фокусу трансформаційної роботи та предметної спрямованості може розглядатися як ефективний концепт творчої зміни «кристалізованих" патернів, відкриття нових векторів життєвих змін, самореорганізації й еволюціонування. Подальший інтерес полягає в обгрунтуванні та змістовому описі екзистенціально-системного конструкту як психологічної технології реорганізації смислової моделі особистості.

\section{Література}

Агафонов А. Ю. Основы смысловой теории сознания. Санкт-Петербург : Речь, 2003. 296 с.

Артемьева Е. Ю. Психология субъективной семантики. Москва : Наука, 1999. $137 \mathrm{c}$.

Бескова И. А. Эволюция и сознание: когнитивно-символический анализ. Москва : ИФ РАН, 2001. 179 с.

Бьюдженталь Дж. Искусство психотерапевта. Санкт-Петербург : Питер, 2001. $304 \mathrm{c}$.

Каліщук С. М. Методика Фреда Е. Фідлера та вірогідність зміни установки особистості щодо інших. Вісник Харківського національного педагогічного університету ілені Г. С. Сковороди. Психологія. 2014. Вип. 48. С. $112-122$.

(C) Kalishchuk Svitlana

DOI (article): https://doi.org/10.32626/2227-6246.2020-48.154-174 
Леонтьев Д. А. Синергетика и личность: к неравновесной персонологии. Методология и история психологии. 2018. Вып. 3. С. 96-104.

Морен Э. Метод: Природа природы. Москва : Канон+, 2013. 464 с.

Сидоренко Е. В. Терапия и тренинг в концепции Альфреда Адлера. Санкт-Петербург : Речь, 2002. 347 с.

Шнайдер К. Пробуждаясь к трепету. Опыт глубинной трансформации истории из жизни. Москва : Корвет, 2015. 224 с.

Adler, A. (1932). What life should mean to you. London : George Allen \& Unwin Ltd. 300 p.

Fidler, F. (1968). Personality and situational determinants of leadership effectiveness. Group dynamics. Research and theory. New York : Harper \& Brothers. P. 137-149.

\section{References}

Agafonov, A. Yu. (2003). Osnovy smyslovoi teorii soznaniia [Fundamentals of the notional theory of consciousness]. Sankt-Peterburg : Rech [in Russian].

Artemieva, E. Yu. (1999). Psikhologiia subektivnoi semantiki [Psychology of subjective semantics]. Moskva : Nauka [in Russian].

Beskova, I. A. (2001). Evoliutsiia i soznaniie: kognitivno-simvolicheskii analiz [Evolution and consciousness: cognitive-symbolic analysis]. Moskva : IF RAN [in Russian].

Biudzhental, Dzh. (2001). Iskusstvo psikhoterapevta [The art of a psychotherapist]. Sankt-Peterburg : Piter [in Russian].

Kalishchuk, S. M. (2014). Metodyka Freda E. Fidlera ta virohidnist zminy ustanovky osobystosti shchodo inshykh [Fred E. Fidler's technique and probability of changing one's personality]. Visnyk Kharkivskoho natsionalnoho pedahohichnoho universytetu imeni H. S. Skovorody. Psykholohiia - Visnyk of H. S. Skovoroda National Pedagogical University, 48, 112-122. Kharkiv [in Ukrainian].

Leontiev, D. A. (2018). Sinergetika i lichnost: k neravnovesnoi personologii [Synergetics and personality: towards nonequilibrium personology]. Metodologiia i istoriia psikhologii - Methodology and history of psychology, 3, 96-104. Moskva [in Russian].

Moren, E. (2013). Metod: Priroda prirody [Method: Nature of nature]. Moskva : Kanon+ [in Russian].

Sidorenko, E. V. (2002). Terapiia $i$ trening $v$ kontseptsii Alfreda Adlera [Therapy and training in the concept of Alfred Adler]. Sankt-Peterburg : Rech [in Russian].

Shnaider, K. (2015). Probuzhdaias $k$ trepetu. Opyt glubinnoi transformatsii - istorii iz zhizni [Awakening to awe. The Experience of Deep Transformation - Life Stories]. Moskva : Korvet [in Russian].

(C) Kalishchuk Svitlana

DOI (article): https://doi.org/10.32626/2227-6246.2020-48.154-174 
DOI: https://doi.org/10.32626/2227-6246.2020-48

2020. ВиПУСК 48

Adler, A. (1932). What life should mean to you. London : George Allen \& Unwin Ltd.

Fidler, F. (1968). Personality and situational determinants of leadership effectiveness. Group dynamics. Research and theory. New York : Harper \& Brothers.

Калішук Світлана. Смислова архітектоніка свідомості й екзистенціально-системний концепт реорганізації "картини світу» майбутніх психологів-консультантів

\section{АНОТАЦІЯ}

у статті висвітлено специфіку смислової архітектоніки свідомості майбутніх психологів-консультантів та окреслено екзистенціально-системний підхід реорганізації їх «картини світу».

"Картина світу» майбутніх психологів-консультантів досліджувалася з використанням таких методів: методу «Найраніший дитячий спогад» А. Адлера; методики Ф. Фідлера "Тип установки щодо інших»; моделювання "семантичних універсалій» "картини світу» за О. Ю. Артем'євою.

Результати дослідження. Проведено аналіз чотирьох складових смислової динаміки «картини світу» досліджуваних, зокрема: становлення "картини світу»; відношення між суб'єктивною моделлю світу й об'єктивним світом; плану змісту та функціонування «картини світу»; розвитку або реорганізації "картини світу». Визначено структуру значущих зв'язків світу досліджуваних і патернів, які вони використовують. Такими атракторами установлено: засоби осягнення "Світу» як джерела страху, суму, сорому, гніву, відрази для підтвердження власних значень відносно суб'єктивного його образу; поведінкові програми уникнення, прохання про допомогу, приєднання, руйнації, відкидання як засоби підтвердження налаштованих зв'язків і засобів взаємодії зі “Світом»; ситуативно-суб'єктивний і нейтрально-байдужий типи установки щодо інших як налаштовані й найефективніші форми взаємовідношення між «Я» $i$ «Світом»; контекстні семантичні універсалії "ресурс та інтенція» i «динаміка» як ґенези розвитку та сили особистісної системи. Охарактеризовано екзистенціально-системний підхід реорганізації смислової архітектоніки майбутніх психологів-консультантів, який передбачає не тільки розширення горизонту бачення себе і світу як дослідження, ви(C) Kalishchuk Svitlana

DOI (article): https://doi.org/10.32626/2227-6246.2020-48.154-174 
значення і прийняття власних експертних зон, а й пошук і встановлення смислових взаємозв'язків між елементами системи завдяки розвитку багатомірності психологічного бачення себе і світу.

Висновок. Запропонована діагностична схема дослідження «картини світу» майбутніх психологів-консультантів забезпечила побудову смислової моделі взаємовідношень конструктів "Я» та «Світ» і розкрила парафермальний досвід конструювання досліджуваними власної архітектоніки смислів з урахуванням їі ґенезису та первісних складових. Екзистенціально-системний підхід у силу мультипарадигмальних методологічних засад і завдань інтегрувати минулий досвід із безмежною власною інтенціальністю, в силу інтрапсихічного фокусу трансформаційної роботи та предметної спрямованості може розглядатися як ефективний концепт творчої зміни “кристалізованих» патернів, відкриття нових векторів життєвих змін, самореорганізації й еволюціонування.

Ключові слова: смисл, "життєвий стиль», "картина світу», екзистенціально-системний концепт, еволюціонування, майбутні психологиконсультанти.

Калищук Светлана. Смысловая архитектоника сознания и экзистенциально-системный концепт реорганизации «картины мира» будущих психологов-консультантов

\section{АННОТАЦИЯ}

В статье освещена специфика смысловой архитектоники сознания будущих психологов-консультантов и охарактеризован экзистенциальносистемный подход реорганизации их «картины мира».

«Картина мира» будущих психологов-консультантов исследовалась с использованием следующих методов: метода "Самое раннее детское воспоминание» А. Адлера; методики Ф. Фидлера "Тип установки отношения к другим»; моделирования "семантических универсалий» «картины мира» по А. Ю. Артемьевой.

Результаты исследования. Проведен анализ четырех составляющих смысловой динамики «картины мира» исследуемых, в частности: становления "картины мира»; отношения между субъективной моделью мира и объективным миром; плана содержания и функционирования «картины мира»; развития или реорганизации «картины мира». Определена структура значимых связей мира исследуемых и паттернов,

(c) Kalishchuk Svitlana

DOI (article): https://doi.org/10.32626/2227-6246.2020-48.154-174 
DOI: https://doi.org/10.32626/2227-6246.2020-48 2020. ВиПУСК 48

которые они используют. Такими аттракторами установлено: способы постижения "Мира» как источника страха, печали, стыда, гнева, отвращения для подтверждения собственных значений относительно субъективного его образа; поведенческие программы избегания, просьбы о помощи, присоединения, разрушения, отвержения как средства подтверждения установленных связей и средств взаимодействия с "Миром»; ситуативно-субъективный и нейтрально-равнодушный типы установки по отношению к другим как наиболее эфрективные формы взаимоотношения между "Я» и «Миром»; контекстные семантические универсалии "ресурс и интенция» и "динамика» как генезис развития и силы личностной системы. Охарактеризован экзистенциально-системный подход реорганизации смысловой архитектоники будущих психологов-консультантов, который предполагает не только расширение горизонта видения себя и мира как исследования, определения и принятия собственных экспертных зон, но и поиск и установление смысловых взаимосвязей между элементами системы благодаря развитию многомерности психологического видения себя и мира.

Вывод. Предложенная диагностическая схема исследования «картины мира» будущих психологов-консультантов обеспечила построение смысловой модели взаимоотношений конструктов "Я» и «Мир» и раскрыла парафермальный опыт конструирования исследуемыми собственной архитектоники смыслов с учетом ее генезиса и первичных составляющих. Экзистенциально-системный подход в силу мультипарадигмальных методологических основ и задачи интегрировать прошлый опыт с безграничной собственной интенциальностью, в силу интрапсихического фокуса трансформационной работы и предметной направленности может рассматриваться как эфрективный концепт творческой смены "кристаллизованных" паттернов, открытие новых векторов жизненных изменений, самореорганизации и эволюционирования.

Ключевые слова: смысл, "жизненный стиль», "картина мира», экзистенциально-системный концепт, эволюционирование, будущие психологи-консультанты.

Original manuscript received February 02, 2020

Revised manuscript accepted March 11, 2020

(C) Kalishchuk Svitlana

DOI (article): https://doi.org/10.32626/2227-6246.2020-48.154-174 